\title{
Anemia in pregnancy and its associated factors: A study from Eastern Nepal
}

\author{
Maskey M1, Jha N², Poudel SI ${ }^{3}$, Yadav D ${ }^{4}$
}

${ }^{1}$ Lecturer, Department of community Medicine, Manipal College of Medical Sciences, Pokhara,

Nepal

2Professor, Department of Community Medicne, Karnali Medical College, Jumla, Nepal

${ }^{3}$ Associate Professor, Department of community Medicine, B.P.Koirala Institutes of Health

Sciences, Dharan, Nepal

${ }^{4}$ Assistant Professor, Department of Community Medicine, B.P.Koirala Institutes of Health

Sciences, Dharan, Nepal

\section{Chief Editor}

\section{Dr. Indrajit Banerjee}

\section{Technical Editor}

Dr. Nishida Chandrasekharan

Formatting Editor

Dr. Brijesh Sathian
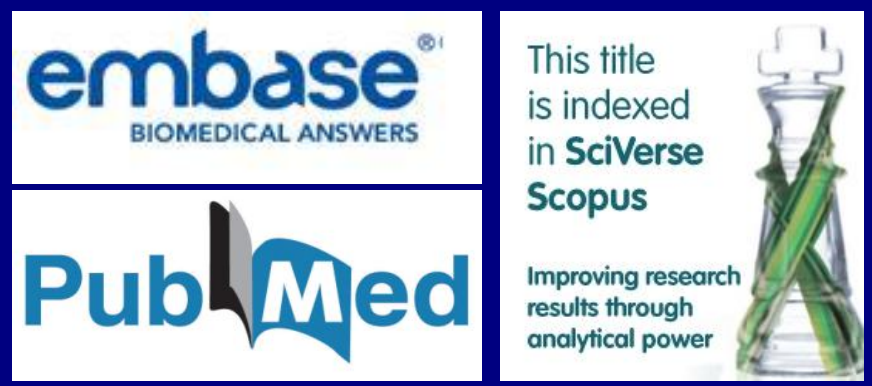

\section{Original Article}

\section{Corresponding Author}

Dr. Manisha Maskey, M.D

Lecturer,

Department of community Medicine,

Manipal College of Medical Sciences,

Pokhara, Nepal

E-mail: manzasharma@gmail.com

\section{Abstract}

\section{Background}

Anemia in pregnancy is responsible for many adverse effects on maternal and fetal outcome. It is the commonest hematological disorder accompanying pregnancy.
Prevalence of anemia among pregnant women is fairly high worldwide, especially in developing countries. A research finding published by World Health organization revels that the prevalence of anemia among pregnant women in developing countries averages 56\% (ranging between 35 to $100 \%)$. Though Nepal has decreasing trend of prevalence of anemia, it is still high (42\% in 2006). Identifying the associated factors which are responsible for the development of anemia during pregnancy would be of great help in mitigating the burden to some extent. Ojective of the study was to find out the pattern of anemia and associated risk factors for anemia during pregnancy.

\section{Materials and Methods}

A cross-sectional study was conducted in VDC named Hansposa. Door to door survey was carried out to collect data using pre-designed questionnaires. Ante-natal checkups were provided with analysis of hemoglobin levels, in 
every individual of study population, using conventional Shali's method. Chi-square test was applied, where applicable.

\section{Results}

Altogether 249 pregnant women were included in the study. The proportion of anemia was found to be $46.6 \%$, the cases of mild anemia, and moderate anemia were $51.0 \%$ and $49.0 \%$ respectively. Risk factors includes: history of complications during previous pregnancy $(P<0.001)$, education $(P<0.05)$, age at marriage $(P=0.028)$, low socioeconomic status $(P<0.001)$, gravidity and parity $(P<0.01)$, poor knowledge about anemia $(P<0.001)$, abnormal body mass index $(\mathrm{P}<0.001)$ and smoking $(\mathrm{P}=0.05)$.

\section{Conclusion}

This study indicates that the prevalence of anemia during pregnancy bears a resemblance to national value. Major associated risk factors include: history of complications during previous pregnancy, low knowledge about anemia in pregnant women, women with low body mass index, age at marriage, socio-economic status, gravidity and parity, and smoking. Most importantly, the lack of commitment in female education plays vital role in its existence.

Keywords: Anemia; Pregnancy; Nepal

\section{Introduction}

Undoubtedly, anemia has become one of the serious public health problems in the world and its widespread prevalence has been widely acknowledged. About one third of the global population (over 2 billion) is anemic. According to World Health Organization (WHO), in developing countries the prevalence of anemia among pregnant women averages $56 \%$, ranging between 35 to $100 \%$ among different regions of the world ${ }^{1}$.

Nepal is one of the least developed countries in the world having low human development indexes: low literacy rate, low life expectancy and low GNI per capita ${ }^{2}$. Moreover, women are even deprived of basic necessities which are essential to live a normal life. Interestingly, Nepal is one of the few countries in the world, where men have longer life span than that of women counterparts ${ }^{3}$. They are subjected to succumb easily to minor illness, especially, during pregnancy. Despite being a physiological condition, its outcome may be quite unpredictable. The success rate depends upon various factors such as associated morbid condition, no. of previous pregnancies, prevailing healthcare delivery system of the country, socio-economic status, literacy status, nature of occupations adopted by females, geographical terrain of the locality, etc ${ }^{4}$.

A decrease in normal number of red blood cells or less than the normal quantity of hemoglobin in the blood is called Anemia ${ }^{5,6}$. Anemia in pregnancy is responsible for many adverse effects on maternal and fetal outcome. It is one of the commonest health problems of pregnant women in developing countries, including Nepal. In 1993, the World
Bank had ranked anemia as the eighth leading cause of disease in girls and women in the developing world ${ }^{7}$. Nepal had prevalence of anemia in pregnant women of $75 \%$ in 1998. The coverage of iron/folic acid supplementation was also very low during at that time. Following the launching of "National Anemia control strategy and iron intensification program in 2003" by the Government of Nepal (GoN), the national coverage of iron supplementation has been increased to $59 \%$ from $23 \%$. Subsequently, the prevalence of anemia among pregnant women also decreased to $42 \%$ in $2006^{8}$.

It is already an established fact that anemia is a disorder with innumerable underlying causes and associated with various risk factors. Though Nepal has decreasing trend of prevalence of anemia, it continues to remain as a serious health threat particularly among women in remote and rural parts in Nepal. Prevalence of anemia is significantly higher in southern plains (the Terai) in comparison to hilly and mountainous regions ${ }^{8}$. The prevalence of anemia may vary from community to community and even within the same region itself. The main objective of the study was to estimate the burden and subsequent potential risk factors of anemia among pregnant women in one of the villages (Village Development Committee, VDC) of Eastern Nepal, named Hansposa.

\section{Material and Methods}

\section{Study design and the participants:}

This was a cross-sectional study carried out in Hansposa VDC, one of the VDCs in Sunsari district, located around 15 kilometers away from Dharan, a town in eastern Nepal.

\section{Data collection:}

The study was carried out from May 2010 to April 2011. After taking the information from the Female community health volunteers about residence of pregnant women, door to door survey was performed. Pre-designed questionnaires were filled while interviewing the women. Every woman was given date and time to come to the Sub Health Post where their physical examinations including height, weight, and blood pressure was taken. They were provided ANC checkups and analysis of haemoglobin levels was done using conventional Shali's method. Anemia was classified as per WHO criteria ${ }^{9}$. Modified Udai Parekh classification was used for socio- economic classification ${ }^{10}$.

Women found to be moderately anemic were advised appropriate treatment and follow up was done after 15 days. Those with no improvement in HB level were sent to BPKIHS for further treatment.

\section{Data processing and analysis:}

The coding list was prepared and master chart prepared manually and the data was entered in Excel software. Entered data were transferred in SPSS version 17.0. Frequencies, Proportions, Mean and Standard deviation (SD) were calculated. Chi- square test and odds ratio were applied to find out the association between risk factors and anemia. $P$ value $<0.05$ was considered as statistically significant. 


\section{Inclusion criteria:}

Pregnant women, irrespective of their gestational age, residing in the study area for more than six months were included in the study.

\section{Exclusion criteria:}

Women not willing to participate in this study, and women with any other known morbid condition were excluded from the study.

\section{Sample size calculation:}

As we could not come across any relevant study in village setting, our sample size was based on findings from NDHS 2006. Based on the knowledge that about $42.0 \%$ of pregnant women in our country are anemic, it is calculated that sample size of 245 pregnant women will provide an estimate of prevalence with $15 \%$ error within $95 \%$ confidence limits.

Ethical committee approval:

Ethical clearance was taken from the ethical committee of the BP Koirala Institute of Health Science.

\section{Result:}

Out of 249 participants, $47.0 \%$ were primi-gravida and $53.0 \%$ were multigravida. Mean age was $24.43 \pm 5.05$ years, ranging between 17 and 42 years of age (table 1 ). Majority of women were Hindus ( $81.9 \%$ ), followed by Buddhists, Muslims, and Christians. Most of the women in this study were housewives, some were farmers, and very few women were involved in occupations like laborers, small business, and services. More than sixty percent of women were belonged to lower middle class of socio-economic strata. Even though $71.1 \%$ were found to be literate, very few, only $12.5 \%$, have made above secondary level of education (table 1).

In this study, anemia was present in almost half $(46.6 \%)$ of the pregnant women. Approximately half of them were moderately anemic, and the other half were mildly anemic (51.0\%, 49.0\% respectively). Mean $\mathrm{Hb}$ level was found to be $10.9 \mathrm{gm} / \mathrm{dl}$ among all the pregnant women, whereas among anemic women the level was $9.6 \mathrm{gm} / \mathrm{dl}$. Factors like level of education, age at marriage, low socio-economic status, history of complications during previous pregnancy, poor knowledge about anemia, smokers, and women having low body mass index were found to be significantly associated with anemia (table 1\&2).
Table 1: Distribution of anaemia by socio-demographic characteristics

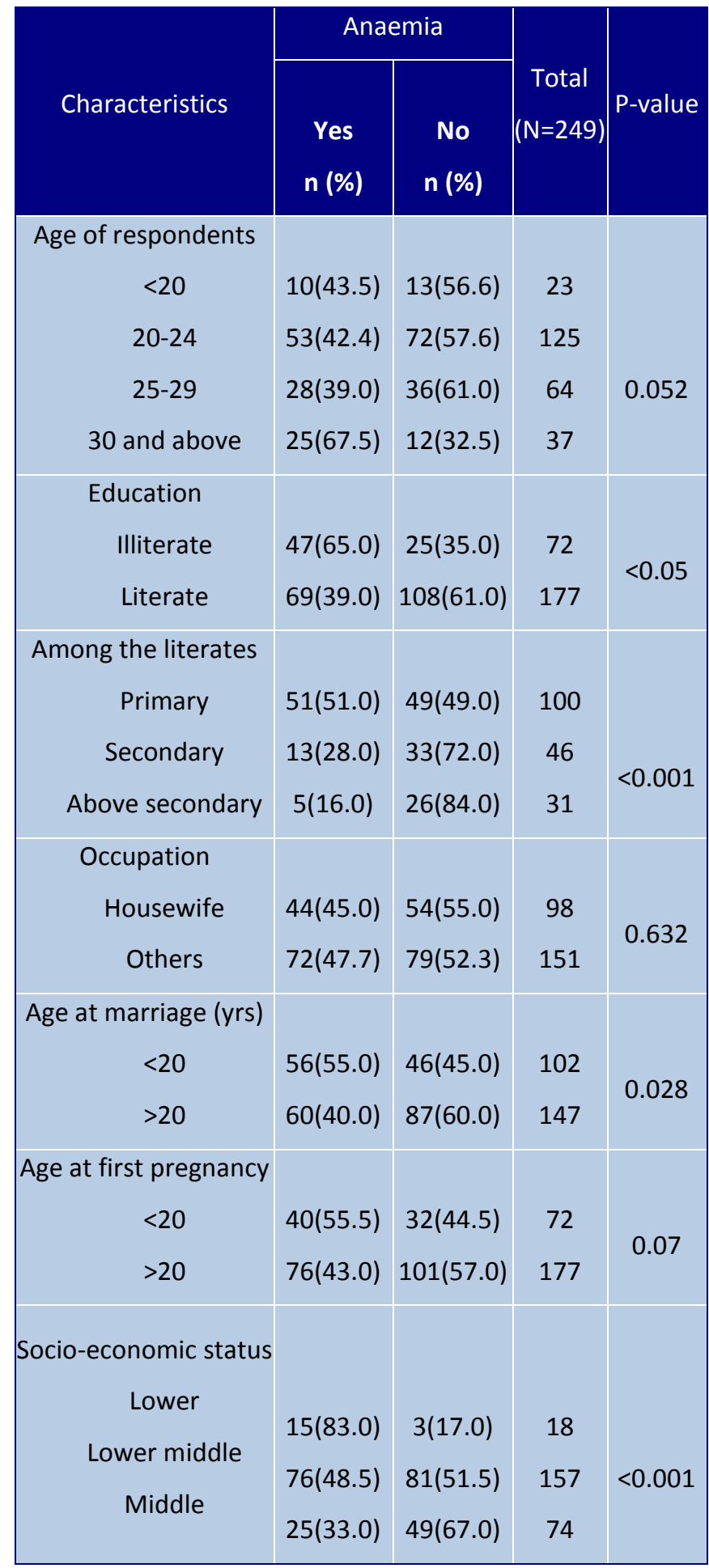


Table 2: Distribution of anaemia by obstetric and other characteristics in pregnant women

\begin{tabular}{|c|c|c|c|c|c|}
\hline \multirow{2}{*}{ Characteristics } & \multicolumn{2}{|c|}{ Anaemia } & \multirow{2}{*}{$\begin{array}{c}\text { Total } \\
(\mathrm{N}=\mathbf{2 4 9})\end{array}$} & \multirow{2}{*}{ Risk } & \multirow{2}{*}{ P-value } \\
\hline & Yes $n(\%)$ & No $n(\%)$ & & & \\
\hline $\begin{array}{c}\text { Deworming } \\
\text { Yes } \\
\text { No }\end{array}$ & $\begin{array}{l}17(47.0) \\
99(46.5)\end{array}$ & $\begin{array}{c}19(53.0) \\
114(45.5)\end{array}$ & $\begin{array}{c}36 \\
213\end{array}$ & & 0.9 \\
\hline $\begin{array}{l}\text { Knowledge } \\
\text { Yes } \\
\text { No }\end{array}$ & $\begin{array}{l}44(32.4) \\
72(64.0)\end{array}$ & $\begin{array}{l}92(67.6) \\
41(36.0)\end{array}$ & $\begin{array}{l}136 \\
113\end{array}$ & 3.6 & $<0.001$ \\
\hline $\begin{array}{c}\text { Complications during immediat } \\
\text { pregnancy } \\
\text { Yes } \\
\text { No }\end{array}$ & $\begin{array}{l}29(76.0) \\
47(49.5)\end{array}$ & $\begin{array}{c}9(24.0) \\
48(50.5)\end{array}$ & $\begin{array}{l}38 \\
95\end{array}$ & & $<0.01$ \\
\hline $\begin{array}{c}\text { Type of complications } \\
\text { Premature delivery } \\
\text { Post-dated delivery } \\
\text { Miscarriage } \\
\text { PPH }\end{array}$ & $\begin{array}{c}1(50.0) \\
3(50.0) \\
12(75.0) \\
13(92.9)\end{array}$ & $\begin{array}{l}1(50.0) \\
3(50.0) \\
4(25.0) \\
1(7.1)\end{array}$ & $\begin{array}{c}2 \\
6 \\
16 \\
14\end{array}$ & & $<0.05$ \\
\hline $\begin{array}{l}\text { Gravida/Para } \\
\text { Primi } \\
\text { Multi } 1-2 \text { child } \\
\text { Multi }>2 \text { child }\end{array}$ & $\begin{array}{l}40(34.0) \\
61(55.0) \\
15(72.0)\end{array}$ & $\begin{array}{c}77(65.0) \\
50(45.0) \\
6(28.0)\end{array}$ & $\begin{array}{c}117 \\
111 \\
21\end{array}$ & & $<0.01$ \\
\hline $\begin{array}{l}\text { Gestation } \\
\text { 1st trimester } \\
\text { 2nd trimester } \\
\text { 3rd trimester }\end{array}$ & $\begin{array}{l}16(59.0) \\
61(48.0) \\
39(41.0)\end{array}$ & $\begin{array}{l}11(41.0) \\
66(52.0) \\
56(59.0)\end{array}$ & $\begin{array}{c}27 \\
127 \\
95\end{array}$ & & 0.22 \\
\hline $\begin{array}{l}\text { Iron } \\
\text { Yes } \\
\text { No }\end{array}$ & $\begin{array}{l}92(44.0) \\
24(57.1)\end{array}$ & $\begin{array}{c}115(55.6) \\
18(42.9)\end{array}$ & $\begin{array}{c}207 \\
42\end{array}$ & 1.6 & 0.1 \\
\hline $\begin{array}{l}\text { Duration of iron } \\
1-2 \text { months } \\
3-4 \text { months } \\
5-6 \text { months }\end{array}$ & $\begin{array}{l}27(38.6) \\
47(51.1) \\
18(40.0)\end{array}$ & $\begin{array}{l}43(61.4) \\
45(48.9) \\
27(60.0)\end{array}$ & $\begin{array}{l}70 \\
92 \\
45\end{array}$ & & 0.2 \\
\hline $\begin{array}{l}\text { Staple diet } \\
\text { Increased } \\
\text { Not increased }\end{array}$ & $\begin{array}{l}50(50.0) \\
66(45.0)\end{array}$ & $\begin{array}{l}50(50.0) \\
83(55.0)\end{array}$ & $\begin{array}{l}100 \\
149\end{array}$ & 0.7 & 0.37 \\
\hline $\begin{array}{c}\text { Additional food } \\
\text { Yes } \\
\text { No }\end{array}$ & $\begin{array}{l}47(56.0 \\
69(47.0)\end{array}$ & $\begin{array}{l}55(54.0) \\
78(53.0)\end{array}$ & $\begin{array}{l}102 \\
147\end{array}$ & 1.03 & 0.89 \\
\hline $\begin{array}{l}\text { Dietary habits } \\
\text { Vegetarian } \\
\text { Non Vegetarian }\end{array}$ & $\begin{array}{c}11(42.0) \\
105(47.0)\end{array}$ & $\begin{array}{c}15(58.0) \\
118(53.0)\end{array}$ & $\begin{array}{c}26 \\
223\end{array}$ & 1.2 & 0.6 \\
\hline $\begin{array}{l}\text { Smoker } \\
\text { Yes } \\
\text { No }\end{array}$ & $\begin{array}{l}22(61.0) \\
94(44.0)\end{array}$ & $\begin{array}{c}14(39.0) \\
119(56.0)\end{array}$ & $\begin{array}{c}36 \\
213\end{array}$ & 1.3 & 0.05 \\
\hline $\begin{array}{c}\mathrm{BMI} \\
<18.5 \mathrm{~kg} / \mathrm{m} 2 \\
18.5-25 \mathrm{~kg} / \mathrm{m} 2 \\
>25 \mathrm{~kg} / \mathrm{m} 2\end{array}$ & $\begin{array}{l}27(75.0) \\
52(46.5) \\
37(36.6)\end{array}$ & $\begin{array}{l}9(25.0) \\
60(53.5) \\
64(63.4)\end{array}$ & $\begin{array}{c}36 \\
112 \\
101\end{array}$ & & $<0.001$ \\
\hline
\end{tabular}



2).

\section{Disease Burden}

Anemia, though widely discussed and highly curable disorder, still exists as a major public health problem in many countries. According to WHO, 'world prevalence of anemia' stands at $24.8 \%$, with huge difference in occurrence between developed and developing countries. ${ }^{11}$ Anemia in pregnancy, in particular, is of special concern as it affects not only the mother but also the growing fetus inside her and beyond that-- and the global prevalence of 'anemia in pregnancy' is still at very high level $(41.8 \%) .{ }^{11}$ The national (Nepal) prevalence of anemia among pregnant women, which also resembles the global prevalence $(42 \%)$, is considered as a severe public health problem. ${ }^{11}$ Even higher local estimate of $46.6 \%$ seen in our study area may suggest that this problem may be of larger magnitude. Similar findings have been noticed in other studies also ${ }^{12,13,14}$.

\section{Anemia and Iron deficiency}

In a study published in British Journal of Hematology in 1998 , at least half of anemic women were attributed to iron deficiency ${ }^{15}$. At present it is almost an established fact that iron supplementation improves maternal iron status. It is reported that iron supplements increase hemoglobin, serum ferritin, mean cell volume, serum iron, and transferrin saturation $^{16-23}$. But the result of our study seems controversial in terms of established facts, as a large proportion of anemic pregnant women were, in fact, taking iron supplementation provided by GoN for free (table 2).

Iron supplementation remains the basic effort of GoN to bring down the prevalence of anemia in pregnant women. It credited "National Anemia control strategy and iron intensification program" for bringing down the prevalence of anemia in pregnant women from $75 \%$ in 1998 to $42 \%$ in $2006^{8}$. Paradoxically, despite the large proportion of women taking iron tablets in this study, still $46.6 \%$ were found to be anemic.

There may be a few factors responsible for that: a) Women in the investigated area may have entered pregnancy with low iron stores in their body. This opens door to further investigations like estimating iron levels in adolescent girls and women in their reproductive age, b) This study did not differentiate types of anemia, so the anemic women may have non iron deficiency anemia, c) The possibility of recall bias of interviewees cannot be ruled out; d) The quality of iron tablets provided to pregnant mothers by GoN, is still a matter of contemplation---and need to be ascertain.

\section{Associated Risk Factors}

Anemia is a complex syndrome entangled by various associated factors. There are innumerable risk factors associated with anemia. Malaria infection and helminthic infestation are leading cause of anemia in pregnancy in most of the developing countries ${ }^{24-27}$. History of taking deworming tablets by the subjects in this study, however, showed insignificant association with anemia $(p=0.3)$. On the other hand, it also showed that risk for anemia
Furthermore, a mother's nutritional status during pregnancy is important, both for the child's intrauterine development and for protection from adverse maternal health ${ }^{8}$. The energy requirements of women are increased above the normal limit during pregnancy ${ }^{28}$. Paradoxically, no association of nutritional factors with anemia was found in this study (table 2). Perhaps the reason behind this paradox is- the proportion of women taking additional food was very low. Women especially in rural area are seem oblivious (or maybe reluctant) about the importance of balanced food during pregnancy.

Meanwhile, low socio-economic status, low educational level, low knowledge of disease, and complication during previous pregnancy, smokers, and women with low body mass index were found to be significantly associated with anemia. Various studies have also confirmed the role of these factors as a potential risk factors for anemia in pregnancy $^{29-33}$. These factors are closely related with each other with education being the foundation of knowledge in every aspect of life.

\section{Conclusion}

The results of this study showed that, even though the national prevalence of anemia in pregnancy is coming down, it is still very high and the fall may be accelerated by very simple means like raising awareness in young girls, pregnant women and their spouses-- about the problem, and educating them the ways to prevent it, monitoring the quality of services and medications provided by the government and anyone else. Most of the associated factors are secondary to formal education. So effort on raising the literacy rate of people, especially among girls, will help tremendously in lowering the magnitude of the problem.

\section{Limitation of the study:}

1. One of the objectives of this study was to find out the risk factors for anemia in pregnancy. Nevertheless, to see the positive association between risk factors and anemia, size of the respondent covered may not be adequate.

2. Stool examination couldn't be performed in this study to see the helminthic load, which is a well-known factor for cause of anemia.

3. Possibility of information bias couldn't be denied.

\section{Relevance of the study:}

Anemia is one of the commonest disorder with immense public health importance as it affects all the age groups, but is more prevalent in pregnant women and young children. These groups are considered as vulnerable groups because the consequences of anemia in these groups are farfetched, in compare to others. One of the most common cause of anemia is iron deficiency anemia, which is mainly related to nutritional deficiency, which can be attributed to other 
socio-economic factors that might be hidden in the community itself. Cause of anemia might be unique for each community. Trying to find out those causes of anemia in pregnancy in each community will definitely lead for better management of this disorder.

\section{Author's Contribution:}

MM participated in designing and development of proposal, data collection, data analysis, statistical analysis. NJ supervised and performed the final data analysis, read, edited and approved the manuscript before submission. ISP participated in data analysis and statistical analysis. DY proof read and edited the proposal and reviewed the manuscript.

\section{Conflict of interest:}

There is no conflict of interest among authors arising from the study.

\section{References:}

1. World Health Organization. The prevalence of anaemia in women: a tabulation of available information, 2nd Ed., Geneva: WHO, 1992.

2. Wikipedia the free encyclopaedia: Nepal [online] [Cited 2010 January 30]. Available from: URL: http://en.wikipedia.org/wiki/Nepal\#cite_note-

The_Kathmandu_Post-5

3. Nepal Report: Report on the State of Women in Urban Local Government [online] [Cited 2010 January 30]. Available from: URL: http://www.unescap.org/huset/women/reports/nepal.pd $\mathrm{f}$

4. Gautam VP, Bansal YY, Taneja DK, Saha R. Prevalence of anemia amongst pregnant women and its sociodemographic associates in a rural area of Delhi. Indian J Community Med. 2002;27(4):157-60.

5. Siamak N. Nabili. Anemia [online] [Cited 2014 January 30]. Available from: URL: http://www.medicinenet.com/anemia/article.htm

6. Definition of Anemia, Merriam-Webster dictionary. [online]. [Cited 2010 January 30]. Available from: URL: http://www.merriam-webster.com/dictionary/anemia.

7. Jackson DJ, Klee EB, Green SD, Mokilli JL, Cutting WA Severe anaemia in pregnancy: a problem of primigravidae in rural Zaire Transactions Royal Society of Tropical Medicine and Hygiene.1991;85:829-832 http://dx.doi.org/10.1016/0035-9203(91)90471-A

8. Nepal demographic and health survey. Population Division, Ministry of Health and Population, Government of Nepal, Kathmandu, 2006.

9. Iron Deficiency: Indicators for Assessment and Strategies for Prevention. World Health Organization (WHO)/United Nations Children's Fund/United Nations University. Geneva, 1998.

10. Pareek Udai and G. Trivedi Reliability and validity of a rural socioeconomic status scale. Indian Journal of Applied

\section{Anemia in pregnancy and its associated factors} Psychology, 1964, 34-40.

11. Worldwide prevalence of anaemia 1993-2005: WHO Global Database on Anaemia [Online]. [Cited 2010 January 30] Available from: URL: http://whqlibdoc.who.int/publications/2008/9789241596 657_eng.pdf

12. M. Adak, S. Nazrid, Prevalence of anaemia among young girls and pregnant women of Birgunj, Nepal, Journal of Institute of Medicine, 2006; 28:2 30-34.

13. Marahatta R. Study of anaemia in pregnancy and its outcome in Nepal Medical College Teaching Hospital, Kathmandu, Nepal. Nepal Med Coll J. 2007;9(4):270-4. PMid:18298019

14. Chotnopparatpattara $\mathrm{P}$, Limpongsanurak $\mathrm{S}$, Charnngam $P$. The Prevalence and risk factors of Anaemia in Pregnantwomen. J Med Assoc Thailand 2003; 86: 10017. 1996; 17(4):369-72.

15. Svanberg B, Arvidsson B, Norrby A, Rybo G, Solvell L. Absorption of supplemental iron during pregnancy:a longitudinal study with repeated bone-marrow studies and absorption measurements. Acta Obstet Gynecol Scand Suppl 1976;48:87-108.

16. Milman N, Agger AO, Nielsen OJ. Iron supplementation during pregnancy. Effect on iron status markers, serum erythropoietin and human placental lactogen. A placebo controlled study in 207 Danish women. Dan Med Bull 1991;38:471-6. PMid:1802636

17. Simmons WK, Cook JD, Bingham KC. Evaluation of a gastric delivery system for iron supplementation in pregnancy. Am J Clin Nutr 1993;58:622-6. PMid:8237866

18. De Benaze C, Galan P, Wainer R, Hercberg S. Prevention of iron deficiency anemia in pregnancy by using early iron supplementation: a controlled trial. Rev 1989;37:109-18.

19. Taylor DJ, Lind T. Red cell mass during and after normal pregnancy. Br J Obstet Gynaecol 1979;86:364-70. http://dx.doi.org/10.1111/j.1471-0528.1979.tb10611.x

20. Fleming AF, Ghatoura GBS, Harrison KA, Briggs ND, Dunn DT. The prevention of anemia in pregnancy in primigravidae in the guinea savanna of Nigeria. Ann Trop Med Parasitol 1986;80:211-33. PMid:3530158

21. Puolakka J, Janne O, Pakarinen A, Vihko R. Serum ferritin as a measure of stores during and after normal pregnancy with and without iron supplements. Acta Obstet Gynecol Scand 1980;95:43-51. http://dx.doi.org/10.3109/00016348009156379

22. Arnold DL, Williams MA, Miller RS, Qiu C, Sorensen TK. Iron deficiency anemia, cigarette smoking and risk of abruptio placentae. J Obstet Gynaecol Res. 2009;35(3):446-52.

http://dx.doi.org/10.1111/j.1447-0756.2008.00980.x PMid:19527381 
23. Iron deficiency anemia: guidelines for prevention, detection and management among U.S. children and women of childbearing age. Institute of Medicine, Food and Nutrition Board, Washington DC. National Academy Press, 1993.

24. Murthy GL, Sahay RK, Srinivasan VR, Upadhaya AC, Shantaram V, Gayatri K. Clinical profile of falciparum malaria in a tertiary care hospital. J Indian Med Assoc. 2000;98(4):160-169.

PMid:11016175

25. Singh N, Shukla MM, Sharma VP. Epidemiology of malaria in pregnancy in central India. Bull World Health Organ. 1999;77(7):567-72. PMid:10444880 PMCid:PMC2557706

26. Verhoeff FH, Brabin BJ, Chimsuku L, Kazembe $P$, Russell WB, Broadhead RL et al An evaluation of the effects of intermittent sulfadoxine-pyrimethamine treatment in pregnancy on parasite clearance and risk of low birth weight in rural Malawi. Ann Trop Med Parasitol. 1998;92(2):141-50.

http://dx.doi.org/10.1080/00034989859979

27. Hawdon JM, Hotez PJ. Hookworm: developmental biology of the infectious process. Curr Opin Genet Dev. 1996;6(5):618-23.

http://dx.doi.org/10.1016/S0959-437X(96)80092-X

28. Park K. Preventive and social medicine. 20th ed. Banarsidas Bhanot, 2009.

29. Desalegn S. Prevalence of anaemia in pregnancy in Jima town, southwestern Ethiopia. Ethiop Med J. 1993; 31(4):251-8.

PMid:8287859

30. Shah BK, Baig LA.Association of anemia with parasitic infestation in pregnant Nepalese women: results from a hospital-based study done in eastern Nepal. J Ayub Med Coll Abbottabad. 2005;17(1): 5-9. PMid:15929517

31. Meda N, Mandelbrot L, Cartoux M, Dao B, Ouangré A, Dabis $F$ et al Anaemia during pregnancy in Burkina Faso, west Africa, 1995-96: prevalence and associated factors. Bull World Health Organ. 1999;77(11):916-22. PMid:10612887 PMCid:PMC2557753

32. Chamberlain G, Steer P, editors. Turnbull's Obstetrics. 3rd ed. Churchill Livingstone edition; 2003.

33. National Family Health Survey (NFHS-2) 1998-1999 India. International Institute for Population Sciences, Mumbai, India \& ORC Macro, Calverton, Maryland, USA; 2000.
Article history

\begin{tabular}{|lc|}
\hline \multicolumn{2}{|c|}{ Article Information } \\
\hline \multicolumn{2}{|c|}{ Article history } \\
\hline Received & $12^{\text {nd }}$ July 2014 \\
Received in revised form & $12^{\text {th }}$ August 2014 \\
Accepted & $12^{\text {rd }}$ September 2014 \\
\hline
\end{tabular}

